\title{
Population structure and genetic diversity of trout (Oncorhynchus mykiss) above and below natural and man-made barriers in the Russian River, California
}

\author{
Kristy Deiner · John Carlos Garza $\cdot$ Robert Coey \\ Derek J. Girman
}

\begin{abstract}
The effects of landscape features on gene flow in threatened and endangered species play an important role in influencing the genetic structure of populations. We examined genetic variation of trout in the species Oncorhynchus mykiss at 22 microsatellite loci from 20 sites in the Russian River basin in central California. We assessed relative patterns of genetic structure and variation in fish from above and below both natural (waterfalls) and man-made (dams) barriers. Additionally, we compared sites sampled in the Russian River with sites from 16 other coastal watersheds in California. Genetic variation among the 20 sites sampled within the Russian River was significantly partitioned into six groups above natural barriers and one group consisting of all below barrier and above dam sites. Although the below-barrier sites showed moderate gene flow, we found some support for sub-population differentiation of individual tributaries in the watershed. Genetic variation at all below-barrier sites was high compared to above-barrier sites. Fish above dams were similar to those from below-barrier sites and had similar levels of genetic diversity, indicating they have not been isolated very long from below-barrier populations.
\end{abstract}

Population samples from above natural barriers were highly divergent, with large $F_{\text {st }}$ values, and had significantly lower genetic diversity, indicating relatively small population sizes. The origins of populations above natural barriers could not be ascertained by comparing microsatellite diversity to other California rivers. Finally, below-barrier sites farther inland were more genetically differentiated from other watersheds than below-barrier sites nearer the river's mouth.

Keywords Trout $\cdot$ Microsatellite $\cdot$ Landscape features · Genetic differentiation · Life history types

\section{Introduction}

Natural and anthropological landscape features, such as mountain ranges, waterfalls, dams and roads can fragment populations and dramatically affect patterns of migration and differentiation (e.g. Castric et al. 2001; Manel et al. 2003). Evaluation of population genetic structure in widespread species is crucial for the development of conservation and management strategies. Therefore, quantifying patterns of gene flow and genetic drift across both natural and man-made barriers to migration are important for determining their effects on population genetic structure. In this study, we examined within-basin population genetic structure of Oncorhynchus mykiss, steelhead or rainbow trout, in the Russian River, California to evaluate the degree of differentiation that occurs on a relatively small scale. We then compared this within-basin genetic structure to that previously described (Garza et al. 2004) for this species throughout the southern part of its native range. 
The trout species $O$. mykiss is the most widespread of the Pacific salmonids, with a native range from Russia to southern California and historically to northern Mexico. In addition, O. mykiss has been introduced to every continent in the world (except Antarctica) for recreational fisheries and aquaculture and has been planted in nearly every body of water in California (Moyle 2002). Because of this species' broad geographic distribution and the diverse topography in its native range, there are considerable diverse phylogenetic and phylogeographic patterns within the species (e.g. Bagley and Gall 1998). Adding to this complexity is the flexibility in life history strategy, with some populations composed largely of migratory (anadromous) individuals, others of largely nonmigratory (resident) individuals and yet others a mixture of the two (Behnke 1972). Even with their complex life history characteristics, individuals with easy ocean access are commonly referred to as steelhead and those without such access as resident rainbow trout.

In spite of their broad geographic distribution and considerable complexity, many populations of steelhead in California and western North America have received protection under the US Endangered Species Act (ESA; Federal Register 1997). In California, five of the six steelhead evolutionarily significant units (ESUs), as described by Busby et al. (1996), are under ESA protection, with the Southern California ESU listed as endangered and the others as threatened. Dams, in particular, have greatly affected migratory fishes in California, as almost all major rivers in the state have been dammed at least once (Reisner 1993). In an attempt to mitigate the loss of spawning habitat for migratory fish because of such dams, many hatcheries have been built to rear and release salmonids. The origin of broodstock and hatchery practices determine whether fish produced at a particular hatchery are included as part of the ESU (Federal Register 1997). In addition, ESA protection has only been extended to fish below barriers to anadromy that are known or expected to be anadromous (Federal Register 1997). However, in practice, this can be nearly impossible to determine, particularly for juvenile fish.

The Russian River is located in central California, with an ocean outfall approximately $90 \mathrm{~km}$ north of San Francisco, and is the largest river in the Central California Coast Steelhead ESU. The basin contains many natural waterfalls, as well as two major dams, Warm Springs (built in 1982) and Coyote (built in 1959). These characteristics make the Russian River basin a good system to study the potential influence of both natural and man-made barriers on migration and gene flow on potentially migratory fish.

In this study, we studied population samples of $O$. mykiss at 20 sites within the Russian River by collected genetic data from 22 microsatellite loci and analyzed patterns of genetic diversity and structure. Sampling included 11 sites above putative natural barriers to anadromy (waterfalls), two sites above dams, five sites below any known barriers to anadromy and two samples of offspring of anadromous adults returning to the two dammed tributaries and bred at hatcheries. We then describe the effects of such barriers on local population structure and diversity. We also compare patterns of genetic structure and diversity within the Russian River with those from 16 other coastal watersheds throughout California. Finally, we discuss implications of the results for conservation and management of this ecologically complex species on the small scales at which restoration strategies are frequently devised.

\section{Materials and methods}

\section{Sampling}

Caudal fin clips were taken, non-lethally, from juvenile trout at five below-barrier sites and from all year classes at 13 above-barrier sites in the Russian River watershed in 2002 (Fig. 1a, Table 1). These sites represent samples from seven tributaries above, between, and below-barriers that were described as impassable to anadromous fish by the California Department of Fish and Game (CDFG 2002). Samples were collected via electrofishing and seining throughout the period prior to the winter run of steelhead (June-October). In addition, the Dry Creek and East Fork Russian River tributaries were studied by analyzing juvenile offspring of anadromous adults that returned to the two dams on these tributaries and were then brought to Warm Springs Hatchery for breeding. Tissue was then collected from their offspring, which were reared separately, before release. Tissue samples were stored in $20 \%$ DMSO-saturated $\mathrm{NaCl}$ storage buffer and frozen at $-20^{\circ} \mathrm{C}$ until processed.

\section{DNA extraction and microsatellite analyses}

Genomic DNA was isolated from fin tissue using a phenol-chloroform iso-amyl alcohol procedure following Taberlet and Bouvet (1991). DNA was visually inspected for quality and quantity on $1.2 \%$ agarose gels. Nine hundred and eight individuals were analyzed with 
Fig. 1 (a) Sites sampled in the Russian River in 2002. Slash marks across waterways indicate barriers, sites were sampled immediately above and below each barrier. *Indicate barriers that are dams, all other barriers are natural, abbreviations as in Table 1. (b) Map of California indicating the Russian River watershed (shaded area) in relationship to the other basins evaluated in this study. Numbers 1-18 and abbreviations for ESUs SCCC, CCC, NC, and KMP correspond to Table 2
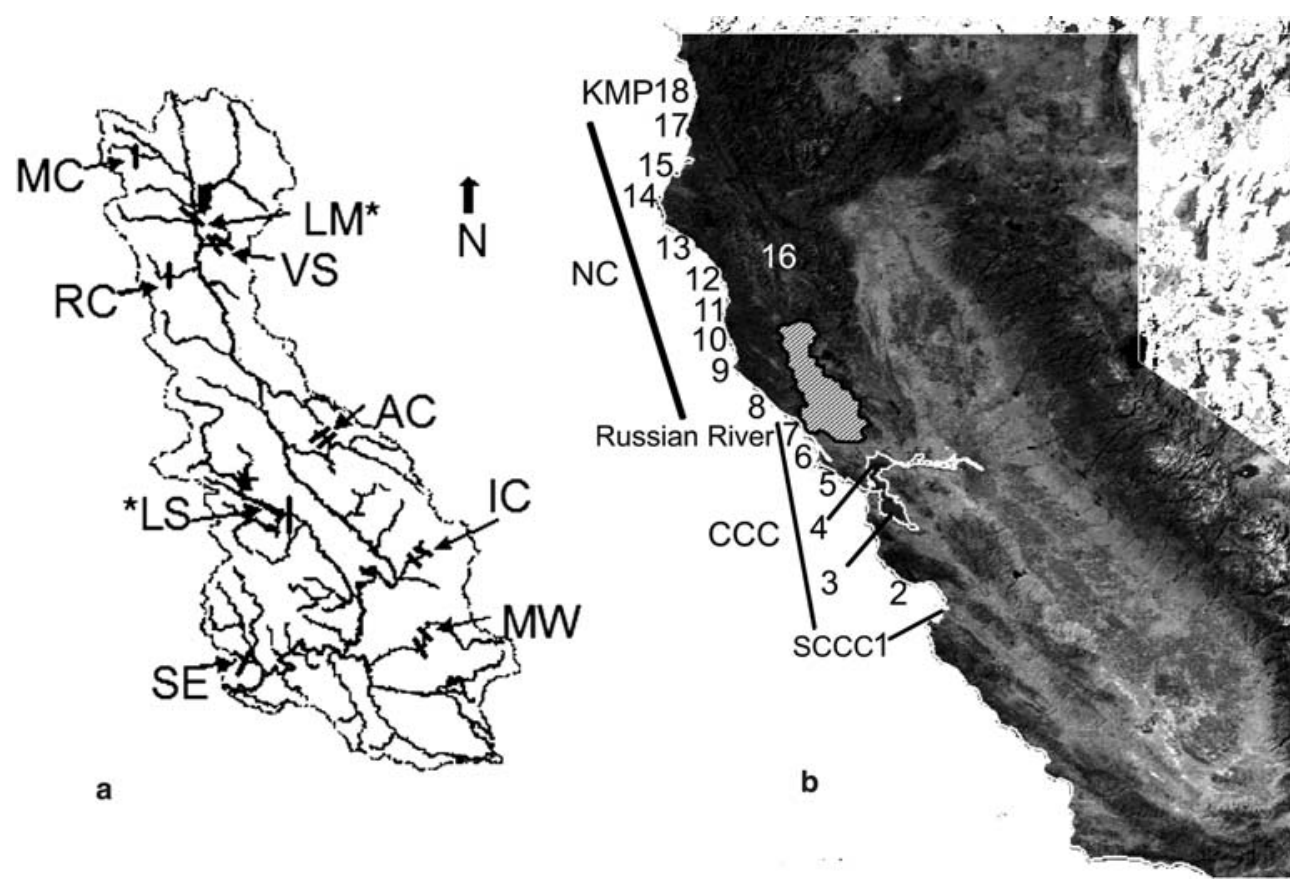

Table 1 Description of sites and samples

\begin{tabular}{|c|c|c|c|c|c|c|}
\hline County & Tributary & Classification & Abbreviation & $N$ & $D(\mathrm{~m})$ & Type of barrier \\
\hline \multirow[t]{2}{*}{ Sonoma } & \multirow[t]{2}{*}{ St. Elmo Creek } & Below & SEB & 39 & 175 & \\
\hline & & Above & SEA & 46 & $>500$ & Three $3.0-\mathrm{m}$ waterfalls \\
\hline \multirow[t]{3}{*}{ Sonoma } & \multirow[t]{3}{*}{ Ingalls Creek } & Below & $\mathrm{ICB}$ & 42 & 102 & \\
\hline & & Middle & $\mathrm{ICM}$ & 48 & 110 & 3.7-m boulder fall \\
\hline & & Above & ICA & 48 & 115 & 21.3-m waterfall \\
\hline \multirow[t]{2}{*}{ Sonoma } & Dry Creek (below Lake Sonoma) & Hatchery & LSB & 48 & a & \\
\hline & Rancheria Creek (above Lake Sonoma) & Above & LSA & 48 & 110 & Dam, built in 1982 \\
\hline \multirow[t]{2}{*}{ Sonoma } & Markwest Creek & Below & MWM & 48 & 74 & \\
\hline & & Above & MWA & 48 & $>200$ & 6.1-m waterfall \\
\hline \multirow[t]{2}{*}{ Sonoma } & Alder Creek & Middle & $\mathrm{ACM}$ & 48 & 110 & \\
\hline & & Above & $\mathrm{ACA}$ & 48 & 183 & $6.7-\mathrm{m}$ waterfall \\
\hline \multirow[t]{2}{*}{ Mendocino } & Robinson Creek & Below & $\mathrm{RCB}$ & 48 & 61 & \\
\hline & & Above & $\mathrm{RCA}$ & 48 & 110 & 21.3-m steep cascade \\
\hline \multirow[t]{3}{*}{ Mendocino } & Vichy Springs Creek & Below & VSB & 16 & 50 & \\
\hline & & Middle & VSM & 48 & 236 & 6.1-m waterfall \\
\hline & & Above & VSA & 48 & $>200$ & $\begin{array}{l}\text { 12.2-m waterfall/old } \\
\text { mining dam above }\end{array}$ \\
\hline Mendocino & East fork Russian River (below Lake Mendocino) & Hatchery & LMB & 48 & a & \\
\hline Mendocino & Busch Creek (above Lake Mendocino) & Above & LMA & 48 & 115 & Dam, built in 1959 \\
\hline \multirow[t]{3}{*}{ Mendocino } & Mill Creek & Below & MCB & 48 & 100 & \\
\hline & & Above & MCA & 45 & $>500$ & 6.1-m waterfall \\
\hline & & & Total & 908 & & \\
\hline
\end{tabular}

County and tributary sampled from the Russian River Watershed. The site abbreviations used in this study, sample size ( $N)$ maximum geographic distance between samples $(D)$, and the type of barrier

${ }^{a}$ These samples represent fin clips taken from fish held at the Warm Springs Hatchery

22 previously described polymorphic microsatellite loci (Table 3). PCR was performed in $10 \mu \mathrm{l}$ or $15 \mu \mathrm{l}$ reactions consisting of Promega reaction buffer or ABI 10X buffer II (Applied Biosystems Inc.), $1.0-3.0 \mathrm{mM}$ $\mathrm{MgCl}_{2}, 0.8 \mathrm{mM}$ dNTPs, $0.1 \mu \mathrm{M}$ each primer (one standard primer and fluorescently labeled primer with the ABI buffer and one or two M13-tailed primers with the Promega buffer), $0.1 \mu \mathrm{M}$ LI-COR IRD700 or IRD800 label (with M13-tailed primers F: CACGACGTTGTAAAACGAC and R: GGATAACAA TTTCACACAGG), 1.25 units Taq DNA polymerase and 20-60 ng genomic DNA. PCR was performed with either a single or a variable, two-stage annealing temperature (Table 3). The basic thermocycling regime 
Table 2 Description of out of basin sites and samples from Garza et al. (2004) that were used for comparisons among watersheds

\begin{tabular}{|c|c|c|c|c|}
\hline ESU & County & River & Tributary & $N$ \\
\hline SCCC & Monterey & Willow Creek (1) & & 88 \\
\hline $\mathrm{CCC}$ & Santa Cruz & San Lorenzo $(2)$ & Zayante & 55 \\
\hline $\mathrm{CCC}$ & Santa Clara & San Francisco Bay South (3) & Los Trancos & 64 \\
\hline $\mathrm{CCC}$ & Marin & San Francisco Bay North (4) & Miller Creek & 70 \\
\hline $\mathrm{CCC}$ & Marin & Lagunitas Creek (5) & & 61 \\
\hline $\mathrm{CCC}$ & Marin & Redwood Creek (6) & & 73 \\
\hline $\mathrm{CCC}$ & Sonoma & Russian $^{\mathrm{a}}(7)$ & Willow Creek & 64 \\
\hline $\mathrm{NC}$ & Mendocino & Gualala (8) & Fuller Creek & 64 \\
\hline $\mathrm{NC}$ & Mendocino & Navarro (9) & Indian Creek & 64 \\
\hline $\mathrm{NC}$ & Mendocino & Noyo $(10)$ & Little North Fork & 64 \\
\hline $\mathrm{NC}$ & Mendocino & Ten Mile (11) & Lower South Fork & 64 \\
\hline $\mathrm{NC}$ & Mendocino & Usal (12) & & 64 \\
\hline $\mathrm{NC}$ & Humboldt & Mattole (13) & South Fork Bear Creek & 81 \\
\hline $\mathrm{NC}$ & Humboldt & Bear (14) & & 63 \\
\hline $\mathrm{NC}$ & Humboldt & Eel $(15)$ & Lawrence Creek & 72 \\
\hline $\mathrm{NC}$ & Humboldt & Middle Fork Eel ${ }^{\mathrm{b}}(16)$ & Plaskett Creek & 41 \\
\hline $\mathrm{NC}$ & Humboldt & Redwood (17) & Lost Man Creek & 56 \\
\hline \multirow[t]{2}{*}{ KMP } & Del Norte & Klamath Moutain Province (18) & Wilson Creek & 48 \\
\hline & & & Total & 1,156 \\
\hline
\end{tabular}

ESU, County, River and tributary from where samples were collected in 2001. Numbers in parentheses refer to location on map in Fig. $1 \mathrm{~b}$ and are used for abbreviations on tree figures, followed by sample size $(N)$ used for analysis in this study

a This is a sample from a tributary on the Russian River sampled in 2001 from Garza et al. (2004)

b Above-barrier sample

was $94^{\circ} \mathrm{C}$ for $3 \mathrm{~min}$; then 9 cycles at $94^{\circ} \mathrm{C}$ for $30 \mathrm{~s}, \mathrm{~N}^{\circ} \mathrm{C}$ (Table 3) for $2 \mathrm{~min}$, and $72^{\circ} \mathrm{C}$ for $30 \mathrm{~s}$; followed by 15 cycles at $92^{\circ} \mathrm{C}$ for $30 \mathrm{~s}, \mathrm{~N}^{\circ} \mathrm{C}$ (Table 3) for $2 \mathrm{~min}$, and $72^{\circ} \mathrm{C}$ for $30 \mathrm{~s}$, with a final step at $72^{\circ} \mathrm{C}$ for $10 \mathrm{~min}$. PCR products were electrophoresed in denaturing $6.5 \%$ polyacrylamide (Urea concentration $7 \mathrm{M}$ ) gels on either a LI-COR Gene ReadIR 4000/4200 or an ABI 377 automated sequencer. Loci genotyped on the LI-COR system had two standards per gel, one a LI-COR size ladder and the other a sequence from a high copy number E. coli plasmid cloning vector pUC19 (New England BioLabs Inc). The allele size for each gene copy was determined independently by at least two people, by visual comparison with a pUC19 sequence. The size standard was used to control for consistency between gels. Approximately 5\% of the samples were rerun to examine the level of consistency across gels and individual genotype scores. Loci genotyped on an ABI sequencer were analyzed using Genotyper software (Applied Biosystems Inc.). In addition, $10 \%$ of the samples were run on both instruments to convert genotypes for six loci (indicated in Table 3) to allow analysis of interbasin variation using a subset of data from Garza et al. (2004).

Intra- and inter-population genetic diversity

Genetic polymorphism within each site, and for all 22 microsatellite loci, was measured as the number of alleles per locus $(A)$, allelic richness $\left(A_{\mathrm{r}}\right.$; number of alleles weighted by samples size), observed $\left(H_{\mathrm{o}}\right)$ and expected heterozygosity $\left(H_{\mathrm{e}}\right)$, and number of private alleles per site $\left(P_{\mathrm{a}}\right) . A, H_{\mathrm{o}}, H_{\mathrm{e}}$, and $P_{\mathrm{a}}$ were calculated using GDA V1.1 (Lewis and Zaykin 2001). $A_{\mathrm{r}}$ was calculated using FSTAT V2.9.3.2 (Goudet 2001). $A_{\mathrm{r}}$ was evaluated for significant differences between above and below-barrier sites and between hatchery and naturally spawning trout sites with 1,000 permutations in FSTAT. $H_{\mathrm{e}}$ was also evaluated for significant differences for the same site groupings using a Wilcoxon's signed-ranks test. The Mill Creek above (MCA) site was excluded from inter-site genetic diversity analyses because of known recent stocking with adult steelhead returning to hatcheries (Dan Logan NOAA, pers. comm.).

\section{Equilibrium tests}

Tests of Hardy-Weinberg (HWE) and linkage disequilibrium (LD) were performed as implemented in Genepop V3.4 (Raymond and Rousset 1997) using the Monte Carlo method with 1,000 batches and 10,000 iterations per batch. Significance levels were corrected for multiple comparisons using the sequential Bonferroni technique at a significance of 0.05 (Rice 1989).

Watershed population structure and barrier analysis

To assess genetic structure of sites sampled above, between, and below barriers, as well as among all sites, 
five approaches were used: (1) Allelic distributions were tested for differentiation across all sites using the genic differentiation test as described by Raymond and Rousset (1995) and implemented with the default values in Genepop V3.4. (2) Weir and Cockerham's (1984) $\theta$ estimator of $F_{\text {st }}$ was calculated using Arlequin V2.0 (Schneider et al. 2000) for all pairwise compari- sons between sites. We refer to the estimator $\theta$ as $F_{\mathrm{st}}$ throughout this paper. The significance of fixation indices was tested using a non-parametric approach described by Excoffier et al. (1992). Average $F_{\text {st }}$ among all sites was estimated using FSTAT. (3) Cavalli-Sforza and Edwards (1967) chord distance $\left(D_{\text {ce }}\right)$ was calculated for all pairwise comparisons among sites

Table 3 Description of loci used in this study

\begin{tabular}{|c|c|c|c|c|c|c|}
\hline Locus & Source species & Reference & Sequence & $T_{\mathrm{a}}\left({ }^{\circ} \mathrm{C}\right)$ & $N_{\mathrm{a}} N_{\mathrm{g}}$ & $S_{\mathrm{bp}}$ \\
\hline $\mathrm{sa} 289^{\mathrm{a}, \mathrm{b}}$ & S. salar & McConnell et al. (1995) & $\begin{array}{l}\text { F: CTTTACAAATAGACAGACT } \\
\text { R: TCATACAGTCACTATCATC }\end{array}$ & 56 & 121,754 & 4 121-145 \\
\hline $\operatorname{tsG} 249^{a, b}$ & O. tshawytscha & Williamson et al. (2002) & $\begin{array}{l}\text { F: TTCTCAGAGGGTAAAATCTCAGTAAG } \\
\text { R: GTACAACCCCTCTCACCTACCC }\end{array}$ & 56 & 171,798 & 3 136-204 \\
\hline Ots1b & O. tshawytscha & Banks et al. (1999 & $\begin{array}{l}\text { F: GGAAAGAGCAGATGTTGTTAA } \\
\text { R: ATGCTATTTCCAGACGGCA }\end{array}$ & $52.8 / 60^{\mathrm{d}}$ & 171,754 & 4 224-316 \\
\hline OtsG423 & O. tshawytscha & Williamson et al. (2002) & $\begin{array}{l}\text { F: AGGCCTGCCAGGCACTAAAGGTAT } \\
\text { R: GCAAGCAAACATGTAGCTTCATGG }\end{array}$ & $52.8 / 60^{\mathrm{d}}$ & 271,786 & 5 101-241 \\
\hline OtsG83b & O. tshawytscha & Williamson et al. (2002) & $\begin{array}{l}\text { F: TAGCCCTGCACTAAAATACAGTTC } \\
\text { R: CATTAATCTAGGCTTGTCAGCAGT }\end{array}$ & 56 & 261,810 & 104-228 \\
\hline OtsG85 $5^{\mathrm{a}, \mathrm{b}}$ & O. tshawytscha & Williamson et al. (2002) & $\begin{array}{l}\text { F: CCATGTCAGCACTGACTTAAT } \\
\text { R: GGATGTTGTTCCTAATGTTTT }\end{array}$ & 56 & 321,804 & $4150-298$ \\
\hline OtsG3 $^{\mathrm{a}, \mathrm{b}}$ & O. tshawytscha & Williamson et al. (2002) & $\begin{array}{l}\text { F: GGACAGGAGCGTCTGCTAAATG } \\
\text { R: GGATGGATTGATGAATGGGTGC }\end{array}$ & 56 & 161,810 & $158-258$ \\
\hline Omy27 & O. mykiss & McConnell et al. (1995) & $\begin{array}{l}\text { F: TTTATGTCATGTCAGCCAGTG } \\
\text { R: TTTATGGCTGGCAACTAATGT }\end{array}$ & 56 & 1,804 & 4 138-156 \\
\hline Omy $77^{\mathrm{a}, \mathrm{b}}$ & O. mykiss & Morris et al. (1996) & $\begin{array}{l}\text { F: CGTTCTCTACTGAGTCAT } \\
\text { R: GGGTCTTTAAGGCTTCACTGCA }\end{array}$ & $55 / 59^{\mathrm{d}}$ & 271,786 & $5105-167$ \\
\hline $\mathrm{sa} 85^{\mathrm{a}, \mathrm{b}}$ & S. salar & O'Reilly et al. (1996 & $\begin{array}{l}\text { F: AGGTGGGTCCTCCAAGCTAC } \\
\text { R: ACCCGCTCСTCACTTAATC }\end{array}$ & $58 / 60^{\mathrm{d}}$ & 211,796 & $5136-214$ \\
\hline Dmm1332 & O. mykiss & Palti et al. (2002) & $\begin{array}{l}\text { GTGTAA } \\
\text { C }\end{array}$ & 52.8 & 1,802 & -253 \\
\hline Omm1329 & O. mykiss & Palti et al. (2002) & $\begin{array}{l}\text { F: GGGAAGTGTTCACCATTACACAAG } \\
\text { R: CATCCAGGAACGCACCTTTA }\end{array}$ & 60 & 261,780 & $181-255$ \\
\hline OtsG409 & O. tshawytscha & Williamson et al. (2002) & $\begin{array}{l}\text { F: GTAGCCATTTGTGTCACCATCATT } \\
\text { R: CATTCTCCTGCCTCACAGAGTTTA }\end{array}$ & $53 / 55^{\mathrm{d}}$ & $4 \quad 1,666$ & 6 84-90 \\
\hline Ots $103^{b}$ & O. tshawytscha & Small et al. (1998) & $\begin{array}{l}\text { F: AGGCTCTGGGTCCGTG } \\
\text { R: TGATATGGTGTGATAGCTGG }\end{array}$ & $53 / 55^{\mathrm{d}}$ & 1,674 & 4 54-92 \\
\hline Omy1011 & O. mykiss & Condrey and Bentzen (1998) & $\begin{array}{l}\text { F: AACTTGCTATGTGAATGTGC } \\
\text { R: GACAAAAGTGACTGGTTGGT }\end{array}$ & $53 / 55^{\mathrm{d}}$ & 181,548 & $132-260$ \\
\hline OtsG243 ${ }^{\mathrm{b}}$ & O. tshawytscha & Williamson et al. (2002) & $\begin{array}{l}\text { F: TTATTAAACTGCACTGTCTAACTACA } \\
\text { R: GTATGCAGCAAGCCAGGTG }\end{array}$ & $53 / 55^{\mathrm{d}}$ & 101,666 & $597-125$ \\
\hline OtsG253b ${ }^{b}$ & O. tshawytscha & Williamson et al. (2002) & $\begin{array}{l}\text { F: CGCTGCAGAAACATTTTCGA }{ }^{\mathrm{c}} \\
\text { R: AATTGGGTCATTAAGGCTCTGTGG }\end{array}$ & $53 / 55^{\mathrm{d}}$ & 291,462 & 2 165-281 \\
\hline OtsG $401^{\mathrm{b}}$ & O. tshawytscha & Williamson et al. (2002) & $\begin{array}{l}\text { F: CTGCCCTGAGAAGCTGGAGTGCTC } \\
\text { R: TTGCCCCACCCTTGCATCTATCCA }\end{array}$ & 60 & 261,612 & 2 165-237 \\
\hline OtsG43 ${ }^{\mathrm{b}}$ & O. tshawytscha & Williamson et al. (2002) & $\begin{array}{l}\text { F: AACTCCCGTTGACAATTTACTGTTG } \\
\text { R: TTTTGGCAAAGTTGGCTACTCTG }\end{array}$ & $55 / 57^{\mathrm{d}}$ & 221,643 & 3 141-205 \\
\hline One $\mu 11 b^{b}$ & O. nerka & Scribner et al. (1996) & $\begin{array}{l}\text { F: GTTTGGATGACTCAGATGGGACT } \\
\text { R: CCTGCTGCCAACACTGTCAA }{ }^{\mathrm{c}}\end{array}$ & $53 / 55^{\mathrm{d}}$ & 1,666 & 5 112-124 \\
\hline $\mathrm{Oki}_{2} 3^{\mathrm{b}}$ & O. kisutch & Smith et al. (1998) & $\begin{array}{l}\text { F: TGTGCTATAGGGTGAATGTGC } \\
\text { R: AACACAGGCATCCCCACTAA }\end{array}$ & $53 / 55^{\mathrm{d}}$ & 221,572 & 2 118-218 \\
\hline One $\mu 13 b^{b}$ & O. nerka & Scribner et al. (1996) & $\begin{array}{l}\text { F: TCATACCCCATGCCTCTTCTGTT } \\
\text { R: GGGTGGAGAGACAGGTATCTTGTC }\end{array}$ & $53 / 55^{4}$ & 201,480 & $206-254$ \\
\hline
\end{tabular}

Annealing temperature $\left(T_{\mathrm{a}}\right)$, total alleles observed $\left(N_{\mathrm{a}}\right)$, total gene copies sampled $\left(N_{\mathrm{g}}\right)$, molecular size range of alleles in base pairs including primer sequence and M13 tail if present $\left(S_{\mathrm{bp}}\right)$

${ }^{a}$ Loci that were converted for between watershed analyses

${ }^{\mathrm{b}}$ Indicate loci used for between watershed analysis

${ }^{\mathrm{c}}$ Modified from original publication (Garza et al. 2004)

d Two-step annealing temperatures, see PCR protocol in methods 
with the GENDIST program in the PHYLIP package V3.57c (Felsenstein 1995). An unrooted neighborjoining (NJ) tree was constructed using the NEIGHBOR application in PHYLIP (Felsenstein 1995). $D_{\text {ce }}$ was chosen since this estimate of genetic distance does not assume population sizes have remained constant and equal (Felsenstein 1995) and has been shown to lead to a higher probability of recovering correct tree topology than other distances (Takezaki and Nei 1996). Trees were visualized with TREEVIEW (Page 1996). To evaluate support for nodes in the NJ tree, 10,000 bootstrapped distance matrices were generated using the SEQBOOT application in PHYLIP, and NJ trees were built with all resulting $D_{\text {ce }}$ matrices. A consensus tree of all NJ trees was then built with the CONSENSE application in PHYLIP (Felsenstein 1995). (4) Population assignment tests were performed across all sites using the semi-Bayesian method, which assumes an equal prior probability density of the allelic frequencies for each locus in each population (Rannala and Mountain 1997) and was carried out using the "leave one out" procedure in Geneclass V1.0.02 (Cornuet et al. 1999). This procedure does not include the individual who is being assigned when allele frequencies are calculated. (5) An analysis of molecular variance (AMOVA) approach as implemented by Arlequin V2.0 was used to partition variation among groups, among sites within groups, and within sites. The fixation indexes of $F_{\mathrm{st}}$ and $F_{\mathrm{ct}}$ were calculated as defined by Weir and Cockerham (1984), Excoffier et al. (1992), and Weir and Cockerham (1996), where $F_{\text {st }}$ is the total variance in genotype frequencies both among sites and among groups and $F_{\mathrm{ct}}$ is the variance in genotype frequencies among groups. Significance of $F_{\mathrm{st}}$ and $F_{\mathrm{ct}}$ were evaluated as described by Excoffier et al. (1992), using a non-parametric permutation approach and 1,000 permutations were performed. Life history differences, geological patterns among sites and stocking history were used to group sites to test hypotheses of structure. The grouping with the highest significant $F_{\text {st }}$ and $F_{\mathrm{ct}}$ values were considered the most probable geographic subdivisions (e.g. Girman et al. 2001).

\section{Comparisons with other watersheds}

Microsatellite data from 16 loci from all Russian River sites were compared to previously described data from O. mykiss in 17 other California watersheds (Garza et al. 2004) that are part of four steelhead ESUs (Fig. $1 \mathrm{~b}$ and Table 2). $F_{\mathrm{st}}$ and significance for all pairwise comparisons of Russian River sites to other watersheds in California were calculated using Arlequin V2.0 (Schneider et al. 2000). Patterns of differ- entiation $\left(F_{\mathrm{st}}\right)$ of individual below-barrier sites compared with other watersheds (excluding hatchery sites) were analyzed by performing a Kruskall-Wallace non-parametric ANOVA. This approach is used to test the null hypothesis that all populations have identical levels of differentiation in inter-basin comparisons. Deviations from this expectation were evaluated with a $\chi^{2}$ test. The geographic distance from the rivermouth to each below-barrier site was used to identify three distance categories within the Russian River (near-mouth, middle and interior). The groupings consisted of St. Elmo Creek samples (14 km from the ocean), Ingalls Creek samples (90 km from the ocean), and samples from Mill Creek, Robinson Creek, and Vichy Springs $(187 \mathrm{~km}, 172 \mathrm{~km}$, and $185 \mathrm{~km}$ from the ocean respectively). If significant differences in divergence from other watersheds as measured by $F_{\text {st }}$ were detected, pairwise $t$-tests under the protection of the ANOVA were conducted. $D_{\text {ce }}$ distances were also generated, an unrooted NJ tree was constructed, and bootstrap analysis was performed as described above.

\section{Results}

\section{Population genetic diversity}

Basic summary statistics of genetic diversity are presented in Table 4 . When sites were grouped by location type (e.g. above vs. below-barrier); genetic variation between groups was significantly different for measured indices of diversity. $A_{\mathrm{r}}$ for fish above natural barriers $(4.0)$ was significantly lower $(P=0.001)$ than for those sampled below-barriers (6.8). Additionally, natural above-barrier sites had significantly lower $H_{\mathrm{e}}$ $\left(\chi^{2}=9.41, P=0.002\right)$ with a mean difference of 0.16 . Estimates of $A_{\mathrm{r}}$ from hatchery-sampled trout representing sites LMB and LSB were not significantly different from naturally spawning populations $(P>0.05)$. However, a comparison of $H_{\mathrm{e}}$ found that it was significantly higher in the naturally spawning below-barrier sites (Table $3 ; \chi^{2}=3.96, P=0.047$ ). Finally, mean $A_{\mathrm{r}}$ estimated from trout above dams (5.9) was not significantly different $(P>0.05)$ from that of hatchery O. mykiss (7.2), and their $H_{\mathrm{e}}$ values, which differed by 0.06 , were also not significantly different $\left(\chi^{2}=2.67\right.$, $P>0.05)$. However, comparisons of mean diversity values that involved both hatchery and above-dam sites had a small number of observations. Consequently, there is a chance that the sample design is such that we do not have the power to accurately assess significant differences that involve hatchery and abovedam sites. However, there are only two major 
Table 4 Diversity measures calculated from all individuals sampled

\begin{tabular}{|c|c|c|c|c|c|c|c|}
\hline Site & $N$ & $A$ & $A_{\mathrm{r}}$ & $H_{\mathrm{e}}$ & $H_{\mathrm{o}}$ & $P_{\mathrm{a}}$ & $A_{\mathrm{p}}$ \\
\hline SEB & 35.0 & 10.0 & 7.1 & 0.72 & 0.70 & 3 & 0.74 \\
\hline SEA & 42.5 & 3.4 & 2.9 & 0.48 & 0.46 & 0 & 1.00 \\
\hline ICB & 39.8 & 11.0 & 7.6 & 0.74 & 0.75 & 10 & 0.86 \\
\hline ICM & 46.1 & 6.4 & 4.7 & 0.61 & 0.59 & 3 & 0.94 \\
\hline ICA & 47.3 & 4.5 & 3.7 & 0.54 & 0.58 & 1 & 1.00 \\
\hline LSB & 44.7 & 10.5 & 7.3 & 0.75 & 0.74 & 6 & 0.96 \\
\hline LSA & 46.1 & 9.4 & 6.3 & 0.69 & 0.68 & 6 & 0.92 \\
\hline MWM & 45.6 & 5.4 & 3.3 & 0.55 & 0.62 & 1 & 0.94 \\
\hline MWA & 45.1 & 3.9 & 3.7 & 0.53 & 0.52 & 3 & 1.00 \\
\hline $\mathrm{ACM}$ & 43.3 & 6.8 & 5.1 & 0.67 & 0.68 & 1 & 0.81 \\
\hline $\mathrm{ACA}$ & 42.1 & 7.0 & 5.5 & 0.69 & 0.66 & 2 & 0.83 \\
\hline $\mathrm{RCB}$ & 44.2 & 9.4 & 6.4 & 0.71 & 0.72 & 1 & 0.88 \\
\hline RCA & 46.7 & 3.2 & 2.8 & 0.46 & 0.50 & 1 & 1.00 \\
\hline VSB & 15.8 & 7.8 & 7.0 & 0.74 & 0.75 & 2 & 0.88 \\
\hline VSM & 46.3 & 5.8 & 4.3 & 0.60 & 0.58 & 6 & 0.85 \\
\hline VSA & 46.0 & 5.4 & 4.3 & 0.59 & 0.58 & 3 & 0.90 \\
\hline LMB & 44.0 & 9.8 & 7.1 & 0.75 & 0.70 & 4 & 0.90 \\
\hline LMA & 45.8 & 7.4 & 5.5 & 0.68 & 0.65 & 1 & 0.98 \\
\hline MCB & 45.0 & 8.6 & 6.2 & 0.72 & 0.79 & 2 & 0.96 \\
\hline MCA & 39.8 & 8.4 & 6.0 & 0.69 & 0.69 & 5 & 0.93 \\
\hline Mean & 42.6 & 7.2 & 5.3 & 0.64 & 0.65 & 3.1 & $91.63 \%$ \\
\hline
\end{tabular}

$N=$ mean sample size; $A=$ mean number of alleles per locus; $A_{\mathrm{r}}=$ allelic richness across all loci; $H_{\mathrm{e}}=$ expected heterozygosity; $H_{\mathrm{o}}=$ observed heterozygosity; $P_{\mathrm{a}}=$ private alleles; $A_{\mathrm{p}}=$ proportion of individuals assigned correctly

permanent dams and two hatchery broodstock collection sites present in the basin, and these sites, therefore, represent all possible observations.

\section{Equilibrium tests}

Tests of HWE found 155 (35\% of locus/population combinations) significant departures from equilibrium and tests of LD found 1,149 significant associations $(26.6 \%)$. After sequential Bonferroni correction only 75 HWE departures were significant (Appendix I, bolded values) which is $17 \%$ of the 440 comparisons. LD significant associations were reduced to 157 departures, which is $3.6 \%$ of the 4,321 comparisons. There was no consistent pattern of heterozygote deficit or excess observed within and among loci (Appendix I). This suggests that null alleles are not a likely explanation for most of the departures.

Cryptic population structure, inbreeding, admixture and sampling of family groups have previously been suggested as possible factors contributing to departures from equilibrium (summarized in Castric et al. 2002). Given the small spatial scale of the sampling (Table 1) and that most individuals sampled are juveniles, inclusion of related individuals in the study is a likely factor contributing to departures from HWE. If sites were non-randomly sampled and juveniles represent progeny of only a few parents this could substantially affect the results. This possibility led to an exploration of relatedness among individuals within sampling localities with 12 loci (1-12 in Table 3). Matrices of the coefficient of relatedness were constructed using Relatedness V5.0.8 (Goodnight and Queller 2001), pairs of individuals with values consistent with full sib status were identified and one randomly chosen individual of each pair was excluded from the dataset.

The treatment to remove pairs of related individuals resulted in a substantial reduction in significant tests of HWE and LD, with $16.6 \%$ (40 out of 240 ) and $9.0 \%$ (94 out of 1,040), respectively. After Bonferroni correction only 12 out of $240(5.0 \%)$ HWE departures were significant and there were no significant LD associations at the 0.05 level. Only slight changes occurred among other statistics related to population structure (data not shown, see Deiner 2004).

However, the removal of related individuals also caused a substantial reduction in sample size, from $N=908$ to $N=545$. This caused concern about reduced power for evaluation of significance in population genetic statistics given that approximately one third of the total genotypic data were excluded. To evaluate whether reduced sample size contributed directly to the reduction in departures from equilibria, 25 data sets were generated from the Mill Creek Below (MCB) and Alder Creek Above (ACA) data with the same number of individuals randomly excluded as were excluded on the basis of the relatedness coefficient. HWE and LD were calculated for each, corrected for multiple tests as before, and compared to the data set with all individuals for this site and the data set 
with individuals excluded based on relatedness. Analysis of the data sets with individuals randomly excluded revealed similar levels of significant tests for HWE and similar proportions of pairs in LD as when all individuals were included, and did not show the marked decrease in the significant number of departures from equilibrium as observed for the data sets with individuals excluded based on relatedness. These results indicate that the decrease in sample size is not responsible for the decrease in significant departures, at least in MCB and ACA, and lends greater support to the hypothesis that related individuals are causing HWE and LD values to be significantly different from expected proportions.

More importantly, the removal of related individuals did not change the biological interpretation of population structure, as might be expected if these individuals were influencing the analyses. Furthermore, in most cases, samples were collected from sites that would be predicted to have small effective population sizes based on habitat availability (i.e. above waterfalls on small tributaries). For some of these above-barrier sites, almost the entire available stream site was sampled in order to collect desired sample sizes. The majority $(74 \%)$ of individuals excluded due to relatedness at the full sib or greater level were sampled from these above-barrier sites. Small effective population sizes are expected to result in departures from both HWE (Pudovkin et al. 1996) and linkage equilibrium (Hill 1981) and the departures observed thus likely reflect the biological reality of these populations and not error due to non-random sampling of kin. Finally, since departures from expected proportions were mostly likely due to family structure in the populations that is consistently present, and reducing the sample size by excluding related individuals would inevitably involve some error, we conclude that such removal would likely result in the introduction of error to the parameter estimates of a similar or greater degree than the inclusion of related individuals. Therefore, the reported analyses include data from all individuals genotyped.

Watershed population structure and barrier analysis

Substantial population genetic structure was found among $O$. mykiss sampling sites in the Russian River. Most of this divergence was among populations above natural barriers. We found significant differentiation across all sites using genic differentiation tests of allelic distributions. Mean pairwise $F_{\text {st }}$ for intrabasin comparisons was 0.156 (range 0.004-0.385; Table 5). All pairwise $F_{\text {st }}$ values were significantly different from 0 $(P<0.05)$ except SEB-LMB $\left(F_{\mathrm{st}}=0.004 ; P=0.06\right)$. Mean pairwise $F_{\text {st }}$ among above-barrier sites $\left(F_{\mathrm{st}}=0.237\right)$ was significantly higher for among belowbarrier sites $\left(F_{\mathrm{st}}=0.048, P=0.001\right)$. The mean $F_{\mathrm{st}}$ between above-barrier sites and below-barrier sites was 0.158 . Pairwise $F_{\text {st }}$ values between sites above and in between (middle) barriers on the same tributary were lower than $F_{\text {st }}$ values between above- and belowbarrier sites on the same tributary (Table 5). There was no significant difference in mean $F_{\text {st }}$ among naturally spawning trout below barriers $\left(F_{\mathrm{st}}=0.048\right)$ and that among naturally spawning trout and hatchery trout $\left(F_{\mathrm{st}}=0.030, P=0.849\right)$.

The $D_{\text {ce }}$ neighbor-joining tree revealed a pattern of differentiation among sites similar to that found with $F_{\text {st }}$ estimates (Fig. 2). Specifically, below-barrier sites exhibited short branch lengths and had low bootstrap support, whereas above-barrier sites had long branch lengths. In addition, when multiple above-barrier sites on the same tributary, they clustered together with short branches and high bootstrap support.

Assignment accuracy at each site ranged from $74.4 \%$ to $100 \%$ (Table 4 ). A total of 832 of 908 individuals were correctly assigned to site of origin (91.6\%). Below-barrier sites tended to have lower assignment accuracy on average than above-barrier sites, with $74.4 \%$ and $81.3 \%$ accuracy, respectively. Individuals from below-barrier sites that were misassigned were typically assigned to other below-barrier sites, whereas the few individuals from above-barrier sites that were misassigned were generally assigned to one of the above-barrier sites from the same tributary (data not shown).

Of the six different hypotheses tested in the hierarchical analysis of molecular variance, the among-site variance was best explained by a grouping of the natural below-barrier sites, the above-dam sites and the MCA site in one group, versus the above-barrier sites for each tributary in separate groups $\left(F_{\mathrm{ct}}=0.116\right.$, $\left.P<0.05 ; F_{\text {st }}=0.173, P<0.05\right)$. However, most of the observed variation $(82.7 \%$ and $84.7 \%)$ in genotype frequencies was due to within-site differences (Table 6).

Russian River compared to other watersheds

Genetic analysis comparing O. mykiss from the Russian River to fish from other watersheds in coastal California (Table 2) revealed patterns similar to that of intra-basin comparisons for the Russian River (interbasin mean pairwise $F_{\text {st }}=0.053$ ). All pairwise $F_{\text {st }}$ values among Russian River sites and those from other 
Table 5 Pairwise $F_{\text {st }}$ across all populations (matrix) and average $F_{\text {st }}$ values $\left(W_{\mathrm{a}}\right)$ comparing Russian River sites to $O$. mykiss populations on other watersheds described in Table 2. Abbreviations are listed in Table 1

Sites SEB SEA ICB ICM ICA LSB LSA MWM MWA ACM ACA RCB RCA VSB VSM VSA LMB LMA MCB MCA

SEB 0

SEA $0.205 \quad 0$

ICB $0.016 \quad 0.1890$

$\begin{array}{lllll}\text { ICM } & 0.081 & 0.245 & 0.079 & 0\end{array}$

$\begin{array}{llllll}\text { ICA } & 0.124 & 0.290 & 0.138 & 0.074 & 0\end{array}$

$\begin{array}{llllllllll}\text { LSB } & 0.013 & 0.188 & 0.021 & 0.097 & 0.149 & 0\end{array}$

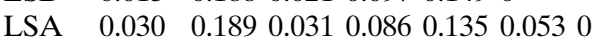

$\begin{array}{lllllllllllll} & \text { MWM } 0.111 & 0.284 & 0.154 & 0.222 & 0.251 & 0.147 & 0.119 & 0\end{array}$

$\begin{array}{llllllllllllll}\text { MWA } & 0.153 & 0.345 & 0.119 & 0.197 & 0.239 & 0.172 & 0.184 & 0.213 & 0\end{array}$

$\begin{array}{llllllllllll}\text { ACM } & 0.112 & 0.269 & 0.114 & 0.173 & 0.194 & 0.111 & 0.127 & 0.227 & 0.200 & 0\end{array}$

$\begin{array}{lllllllllllll}\text { ACA } & 0.084 & 0.244 & 0.077 & 0.142 & 0.167 & 0.076 & 0.087 & 0.205 & 0.166 & 0.029 & 0\end{array}$

$\begin{array}{lllllllllllll}\text { RCB } & 0.035 & 0.218 & 0.044 & 0.106 & 0.154 & 0.041 & 0.059 & 0.151 & 0.180 & 0.128 & 0.089 & 0\end{array}$

$\begin{array}{llllllllllllll}\text { RCA } & 0.175 & 0.385 & 0.189 & 0.260 & 0.292 & 0.209 & 0.212 & 0.305 & 0.331 & 0.263 & 0.238 & 0.217 & 0\end{array}$

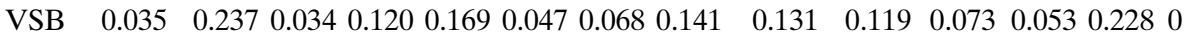

$\begin{array}{llllllllllllllll}\text { VSM } & 0.132 & 0.316 & 0.139 & 0.204 & 0.238 & 0.137 & 0.162 & 0.250 & 0.276 & 0.207 & 0.174 & 0.163 & 0.285 & 0.151 & 0\end{array}$

$\begin{array}{llllllllllllllllllll}\text { VSA } & 0.130 & 0.309 & 0.140 & 0.210 & 0.244 & 0.138 & 0.165 & 0.247 & 0.281 & 0.210 & 0.176 & 0.166 & 0.292 & 0.161 & 0.035 & 0\end{array}$

$\begin{array}{lllllllllllllllllll}\text { LMB } & 0.004 * & 0.184 & 0.012 & 0.089 & 0.146 & 0.025 & 0.044 & 0.145 & 0.141 & 0.106 & 0.068 & 0.028 & 0.202 & 0.026 & 0.132 & 0.138 & 0\end{array}$

$\begin{array}{lllllllllllllllllllllll}\text { LMA } & 0.070 & 0.252 & 0.065 & 0.141 & 0.183 & 0.068 & 0.089 & 0.195 & 0.169 & 0.142 & 0.103 & 0.091 & 0.259 & 0.074 & 0.174 & 0.185 & 0.060 & 0\end{array}$

$\begin{array}{llllllllllllllllllllllll}\text { MCB } & 0.037 & 0.210 & 0.037 & 0.103 & 0.143 & 0.047 & 0.057 & 0.133 & 0.204 & 0.111 & 0.080 & 0.063 & 0.217 & 0.069 & 0.142 & 0.140 & 0.031 & 0.085 & 0\end{array}$

$\begin{array}{llllllllllllllllllllllllll}\text { MCA } & 0.037 & 0.233 & 0.043 & 0.104 & 0.134 & 0.047 & 0.043 & 0.112 & 0.176 & 0.121 & 0.082 & 0.055 & 0.234 & 0.048 & 0.168 & 0.171 & 0.035 & 0.077 & 0.052 & 0\end{array}$

$\begin{array}{lllllllllllllllllllllllllll}W_{\mathrm{a}} & 0.024 & 0.215 & 0.041 & 0.109 & 0.153 & 0.057 & 0.065 & 0.141 & 0.180 & 0.124 & 0.088 & 0.059 & 0.216 & 0.063 & 0.156 & 0.161 & 0.046 & 0.085 & 0.061 & 0.068\end{array}$

All pair-wise $F_{\text {st }}$ values are significant $* P<0.05$, except SEB to LMB $(P=0.06)$

Fig. 2 Neighbor joining tree constructed from chord distances $\left(D_{\text {ce }}\right)$ using allele frequencies from the 22 microsatellite loci listed in Table 2. Bootstrap support above $65 \%$ (10,000 replicates) is indicated by gray branches. Abbreviations as in Table 2

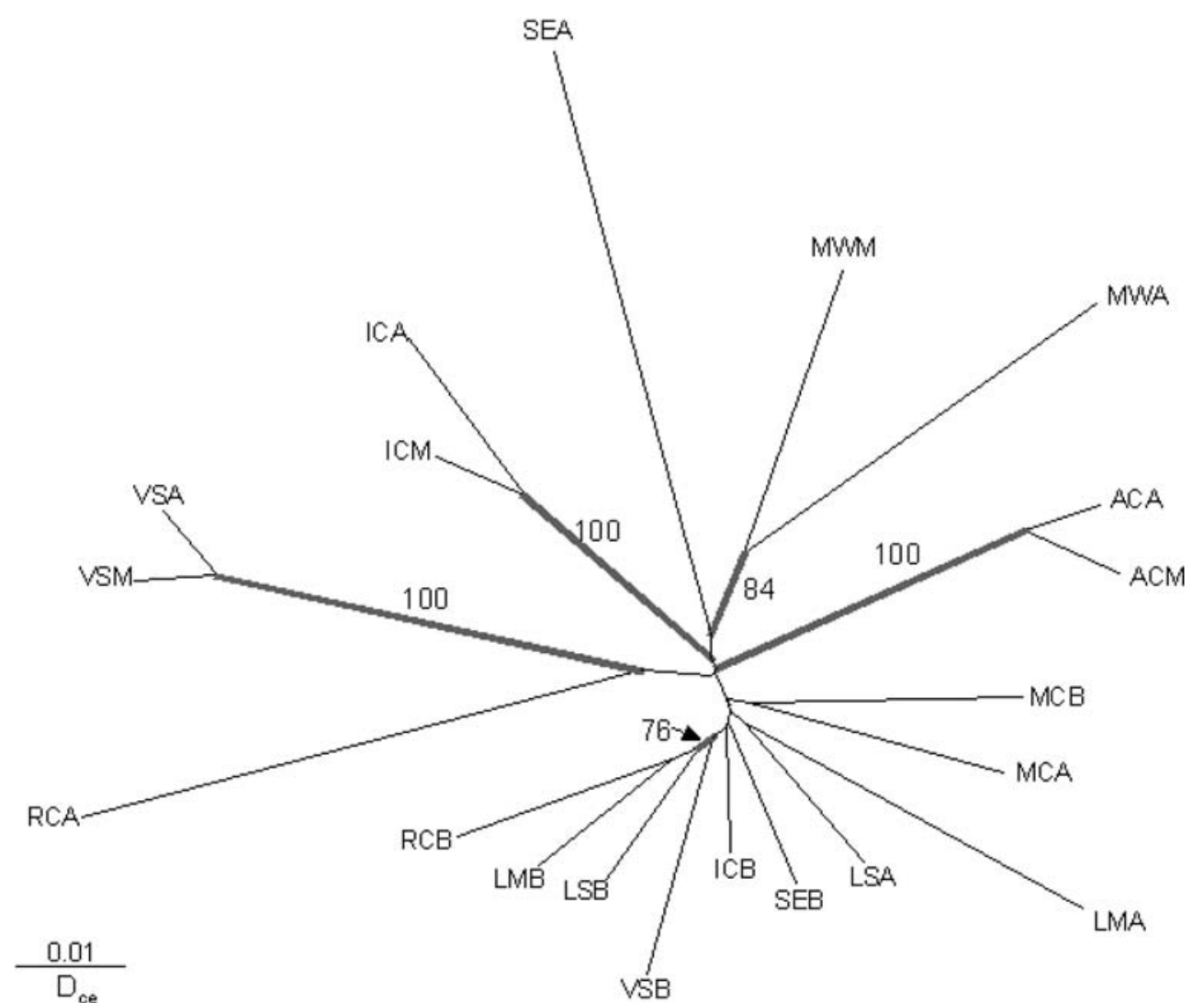

basins were significant $(P<0.05)$. Moreover, a significant pattern of increasing differentiation of belowbarrier sites (excluding the hatchery samples) to other watersheds was detected with increasing distance from the mouth of river $\left(\chi^{2}=38.05, P<0.001\right)$. For example, SEB, near the mouth (14 $\mathrm{km}$ from the ocean) 


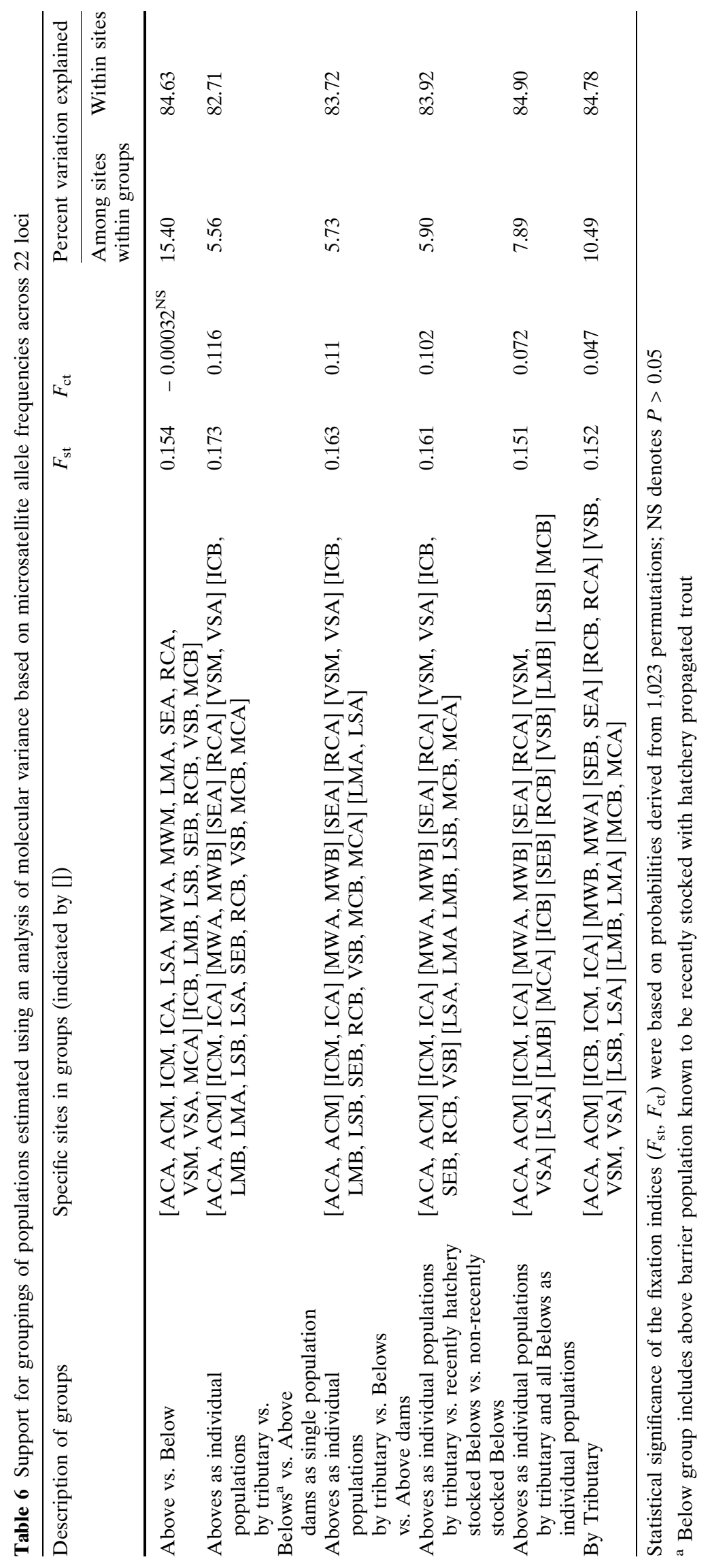


Fig. 3 Neighbor joining tree constructed from chord distances $\left(D_{\text {ce }}\right)$ using allele frequencies from 16 microsatellite loci listed in Table 3. Bootstrap support above $65 \%$ (10,000 replicates) is indicated by gray branches. Russian River sites which are also in the Central California Coast ESU are indicated by bolded branches.

Abbreviations for Russian River sites and numbers corresponding to other rivers are found in Tables 1 and 2, respectively

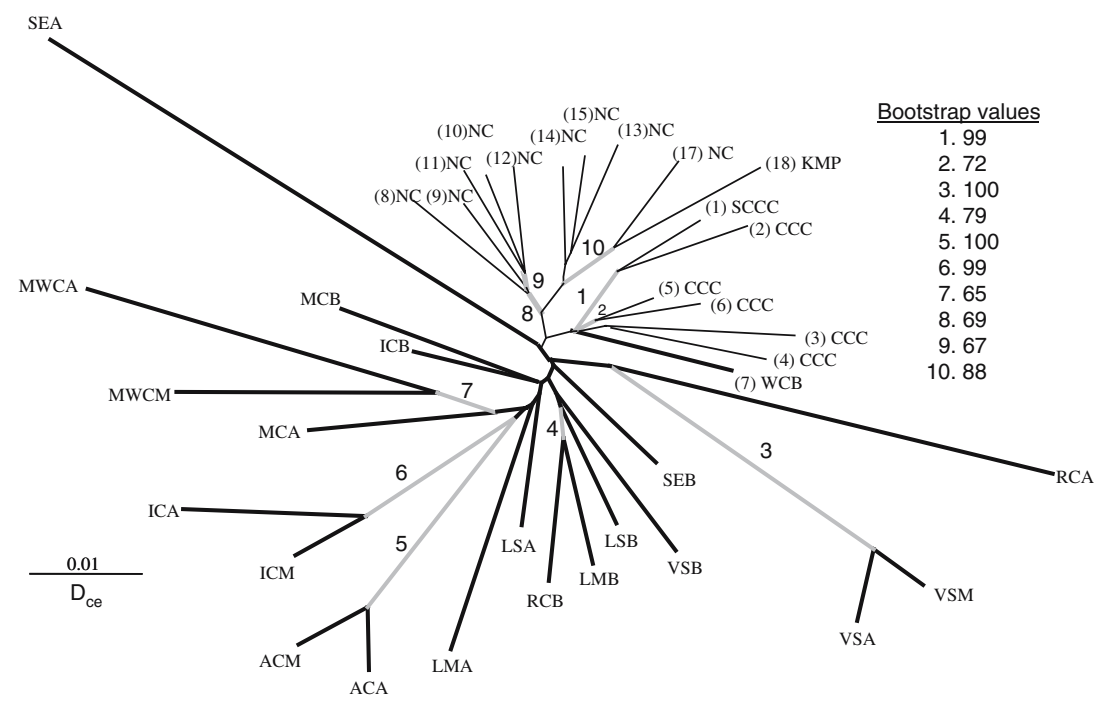

had an average pairwise $F_{\text {st }}$ of 0.024 , while ICB near the middle of the watershed (90 $\mathrm{km}$ from the ocean) had an average pairwise $F_{\text {st }}$ of 0.041 , and the three interior sites (average distance from the ocean of $183.7 \mathrm{~km}$ ) had an average pairwise $F_{\text {st }}$ of 0.061 . Pairwise $t$-tests under the protection of the ANOVA were significant for all comparisons among geographic categories (near mouth, middle, interior) based on distance from the ocean. Pairwise $F_{\text {st }}$ values measured between Russian River above-barrier sites to belowbarrier sites from other watersheds was comparable in degree (mean pairwise $F_{\text {st }}=0.159$ ) to the differentiation estimated between above-barrier and below-barrier sites within the Russian River. The $D_{\text {ce }} \mathrm{NJ}$ tree found the above-barrier sites to be highly differentiated from below-barrier sites in other watersheds with bootstrap values on branches leading to above-barrier populations similar to those of the within-basin tree (Figs. 2, 3).

\section{Discussion}

Genetic analysis of population structure for the trout species $O$. mykiss in the Russian River revealed contrasting results for sites below barriers to anadromy and those found above man-made (dams) and natural (waterfalls) barriers. The seven samples from sites with easy ocean access had similar genetic composition and limited genetic differentiation, indicating recent gene flow among them. Additionally, the two samples from above dams were similar to those from below-barrier sites, both in terms of genetic composition and diversity, indicating they are not highly divergent from below-barrier sampling localities. In contrast, most of the samples from above natural barriers were highly divergent and had evidence of small population sizes.

Below-barrier sites

Comparison of below-barrier sites, which are presumed to contain mainly anadromous fish, revealed significantly less genetic structure than sites above barriers. Results of the AMOVA suggest that the best way to account for the variation in the data is to treat the below-barrier sites as a single population. However, the relationships among below-barrier sites are complex. The assignment tests performed across all sites assigned most individuals to their site of collection $(91 \%)$, yet the misassignments were almost entirely among below-barrier sites, supporting a hypothesis of moderate gene flow among below-barrier sites and that each site may retain some level of genetic distinction, likely due to tributary-level homing ability. Comparisons to recent studies of within-watershed analyses suggest that the levels of divergence found among below-barrier sites in the Russian River are either similar or relatively low (Carlsson and Nilsson 2001; Spidle et al. 2001; Wenberg and Bentzen 2001; Olsen et al. 2003; Poissant et al. 2005; Crispo et al. 2006). However, a study of temporal variation should be undertaken to determine whether different tributaries support differentiated populations or whether the significant $F_{\text {st }}$ values and assignment results are due to transient, kin-based correlations within sites due to sampling juveniles.

Juvenile hatchery trout were not highly differentiated from the juveniles of naturally spawning adults below barriers and thus do not appear to be highly divergent stocks. A review of stocking history of 
steelhead trout over the last century, summarized by Steiner Environmental Consulting (1996), revealed that during the period of 1911-1995 an estimated 29.9 million fish from the species of $O$. mykiss were released in the Russian River and that $49 \%$ were from Russian River broodstock. Other known sources of broodstock during this period include $16 \%$ from the Eel River, $4 \%$ from a combination of California rivers including Mad River, Prairie Creek, San Lorenzo Creek, and Scott Creek, and 1\% came from Washougal, WA. Broodstock for $30 \%$ of these fish were of unknown origin. Despite the considerable number of out-of-basin broodstock sources, results from this study and Garza et al. (2004) suggest that the Russian River population has not been dramatically altered by hatchery releases.

When below-barrier sites on the Russian River were compared to the 16 other coastal watersheds, genetic differentiation was significantly greater among comparisons to interior sites than to those sampled closer to the river mouth. It may be the case that tributaries closer to the mouth of rivers experience higher gene flow from other watersheds than do interior tributaries. The different phylogeographic patterns observed for downstream and interior sites highlight the importance of gene flow from neighboring basins in shaping withinbasin population structure. Additional study is needed to determine what effect intrabasin differentiation has on interbasin comparisons.

There were no substantial differences in genetic diversity among below-barrier sites and those of fish propagated from adult steelhead returning to the two dams on the Russian River. There is a large body of research demonstrating that hatchery-propagated salmonids can be less fit than naturally spawned ones (Healey 1991; Heard 1991; Quinn 1993; Moran et al. 1994; Fleming et al. 1996), although this has generally been studied in situations where the hatchery fish are from a distinct stock propagated mainly from hatchery adults, unlike the hatchery protocol followed here, in which mainly non-hatchery produced fish are used as broodstock. However, microsatellite loci generally measure neutral genetic variation and are not a direct estimate of adaptive variation. Even so, the retention of genetic variation probably means that the populations also retain much of their adaptive potential (Sherwin and Moritz 2000).

\section{Above-dam sites}

Trout sampled above the two dams were not highly differentiated from those sampled at below-barrier sites, with $F_{\text {st }}$ values similar to comparisons among below-barrier sites. In addition, misassignments were typically to below-barrier sites, a pattern rarely found with sites above natural barriers (data not shown). The AMOVA results suggest that the variance in genotype frequencies found in the two sites above dams are best explained by grouping these sites with below-barrier sites (Table 6).

Resident rainbow trout stocked above dams in the Russian River are the product of CDFG broodstock programs at various hatcheries around the state. Records indicate that approximately five different strains of rainbow trout were planted, but none have been planted below barriers since 1958 (SEC 1996). Historically, approximately 21,000 resident rainbow trout were planted annually in the East Fork Russian River above Coyote Dam and Lake Mendocino (SEC 1996). Given the extensive stocking history above this lake, it is perhaps surprising that a greater amount of differentiation of the LMA site from below-barrier samples was not found. However, it may be the case that the stocked trout have not widely affected the genetic composition of fish spawning in tributaries that feed into the lake.

Sites sampled above the two dams possessed levels of heterozygosity and allelic richness that were not significantly different from those of the hatcheries below, suggesting that trout sampled above the two dams have not lost substantial diversity since they were isolated from trout sampled below. At least one study suggests that isolation by a dam can cause a loss of genetic variation in trout populations that are trapped above (Nielsen et al. 1997). The higher levels of genetic diversity in this study can possibly be explained by the fact that the dams are recent (25and 45-years old) and genetic drift may not have had enough time to erode ancestral genetic variation (Srikwian and Woodruff 2000), but it is likely also due to the subsequent movement of adult steelhead above the dams (Brett Wilson, CDFG, pers. comm.). Another possible factor contributing to the higher levels of genetic diversity measured in the abovedam sites compared to the sites above natural barriers is that there is still sufficient habitat above the dams to support larger populations. There are numerous tributaries that feed into the reservoirs (Lakes Sonoma and Mendecino), and it is likely that there is migration among them. Lake-dwelling rainbow trout typically migrate from lakes up into tributaries to spawn (Northcote 1969), as do some other closely related inland trout populations (Neraas and Spruell 2001). However, the extent of gene flow between different tributaries feeding into the reservoirs should be further evaluated and continued monitoring of genetic diversity in these above-dam sites 
should be done to determine the potential future effects that dams may have on the loss of genetic diversity.

\section{Above natural barrier sites}

Most of the observed genetic structure in the Russian River was due to trout sampled from above natural barriers to anadromy in the different tributaries. These trout populations (excluding MCA) were characterized by large pairwise $F_{\text {st }}$ values and long branches on the $D_{\text {ce }}$ tree to most other populations in the study. Comparisons among above-barrier sites from different tributaries of the Russian River had the largest $F_{\text {st }}$ values in the study. Such comparisons involve populations that are geographically distant and physically separated by multiple barriers to migration. Additionally, these populations almost certainly contain smaller numbers of individuals than those from below barriers because of the limited amount of habitat available (Hilderbrand and Kershner 2000). Small population size in above-barrier populations was observed during sampling. For example, the RCA and SEA sites were exhaustively sampled from barrier to headwaters and less than 60 fish were found in each stream, whereas at the below-barrier sites, a similar number were captured in a small fraction of the stream (Table 1).

The high levels of genetic differentiation found across the barriers were largely due to differences in the frequencies of shared alleles rather than differences in allele presence or absence. Comparisons between two sites on the same tributary that were both above a barrier to anadromy, but also separated by another natural barrier (i.e. comparisons of above and middle sites), were characterized by low $F_{\text {st }}$ values and lower assignment accuracies. Additionally, they always grouped together with short branch lengths and very high bootstrap support on the $D_{\text {ce }}$ tree. This characteristic pattern between above and middle sites on the same tributary was observed to a lesser degree on Mark West Creek, possibly because of the recent removal of the barrier below both sites and subsequent immigration of steelhead into the MWM site. The close relationships of multiple above-barrier sites on the same tributary suggests that these populations have had levels of gene flow across the waterfall that is similar in magnitude to the amount of gene flow among trout sites below barriers in the Russian River or that they are both the result of stocking from the same source population.

Ubiquitous stocking of hatchery rainbow trout in most bodies of water in California for the last century has likely also contributed to the high differentiation of these sites. While much movement and stocking of rainbow trout is either unrecorded or using fish of unknown origin, a summary of the recent history of fish movement and plantings in the Russian River (SEC 1996) suggests that no organized stocking effort of hatchery rainbow trout has occurred above natural barriers since 1958. In addition, several studies have demonstrated a lack of significant genetic introgression of hatchery stocks into wild populations (Wishard et al. 1984; Currens et al. 1990; Waples 1991; Williams et al. 1997; LeClair et al. 1999). However, complicating matters is that many of the hatchery stocks used for planting in California appear to have originated from coastal trout of the same subspecies $(O$. mykiss iride$u s$ ), and specifically from stocks in the San Francisco Bay area (Benhke 2002), which is in the same ESU as the Russian River. Unfortunately, we did not have appropriate reference samples from hatchery rainbow trout stocks to ascertain whether the above natural barrier populations studied here originated from vicariant events, stocking with hatchery rainbow trout or some combination of the two.

The amount of genetic variation in the sites above natural barriers was significantly lower than that of below-barrier sites for most measures of diversity $\left(A_{\mathrm{r}}\right.$ and $H_{\mathrm{e}}$ ). This finding was congruent with those of two other studies that used either elevation as a surrogate for above-barrier sites (brook charr; Castric et al. 2001) or examined known landlocked sites (Atlantic salmon; King et al. 2001). Given the degree of isolation, limited habitat, unidirectional migration over waterfalls, and consequeny smaller population sizes of these natural above-barrier populations, genetic drift is likely the major force causing the lower genetic variation, as well as at least partially causing the large genetic distances (Nei et al. 1975; Hedrick and Gilpin 1997).

The MCA site was the only site that did not fit the general pattern of other above natural barrier sites. Pairwise $F_{\text {st }}$ values for MCA to below-barrier sites were low and the $D_{\text {ce }}$ tree topology indicated that MCA is more closely related to below-barrier sites. The MCA site also had genetic diversity greater than all other above natural barrier sites. However, this site is known to have been recently stocked with steelhead adults returning to both dams (Dan Logan, NOAA; pers. comm.). MCA thus provided a good comparison to other above-barrier sites, indicating that they have likely not been similarly affected by recent stocking from local anadromous fish.

\section{Conservation implications}

The results of this study indicate that $O$. mykiss below barriers in the Russian River are best treated as a 
single, large, genetically interacting population with moderate sub-population structure. Since genetic connectivity is indicative of demographic connectivity, below-barrier sites should be treated as a single population in population viability analyses. Additionally, the finding that trout samples in tributaries above the two major dams do not show high levels of genetic distinction from trout sampled below barriers and do not appear to be inbred, indicates that they may be suitable for use in restoration and recovery activities. The substantial differences between populations above and below natural barriers on the same tributary indicate that they are not interacting substantially, although it is possible that some gene flow occurs from above to below barriers on some tributaries.

The results presented here suggest that analyses of population structure and diversity within watersheds, in addition to consideration of among-basin and ESU level structure, provides important insights for management of $O$. mykiss populations. Currently, O. mykiss above and below putative barriers to anadromy are typically regarded as separate populations, have different levels of conservation protection, and are managed separately. However, as stated in the status review for this species that resulted in the ESA listings, managers often remain uncertain regarding the genetic connectivity between putative resident and anadromous fish (Busby 1996). In this context, our results make clear that specific above-barrier sites are, genetically, very distinct populations from those with access to the ocean, whereas other above-barrier sites are not. Therefore, all putative above-barrier sites may not warrant the same management approach. This and other recent studies (e.g. Poissant et al. 2005; Crispo et al. 2006), demonstrate how an evaluation of landscape features and their impact on gene flow can be a valuable tool, among many, to accurately assess population structure and help managers in development of conservation plans for species protected under the US Endangered Species Act.

Acknowledgements We thank B. Freel for the initial inspiration for this project. We also thank K. Adams, L. GilbertHorvath, M. Hachmyer, A. Martinez, S. McNeil, J. Neilsen, J. Philips, S. Thibault, and T. Weiseth for their valuable contribution to this study in the field and in the lab. Additionally, we thank reviewers at the California Academy of Sciences, D. Pearse, R. Waples, and two anonymous reviewers for comments and suggestions that greatly improved the manuscript. This research was funded in part by a grant from the California Department of Fish and Game (Agreement No. P0030495) and in part by Sonoma State University and NOAA Fisheries. 


\begin{tabular}{|c|c|}
\hline$\frac{\mathrm{J}}{2}$ & 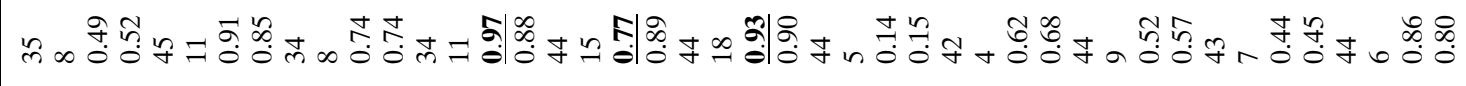 \\
\hline$\frac{0}{\tilde{z}}$ & 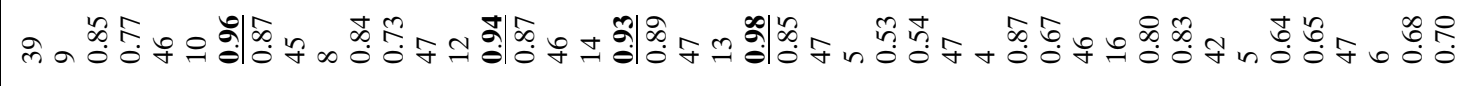 \\
\hline$\stackrel{\infty}{>}$ & 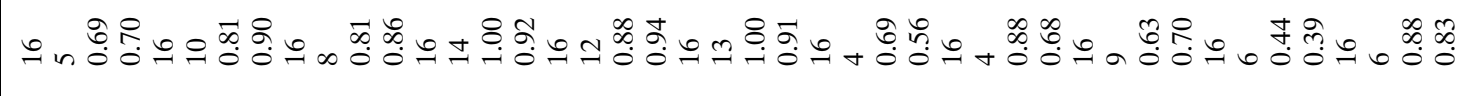 \\
\hline 离 & 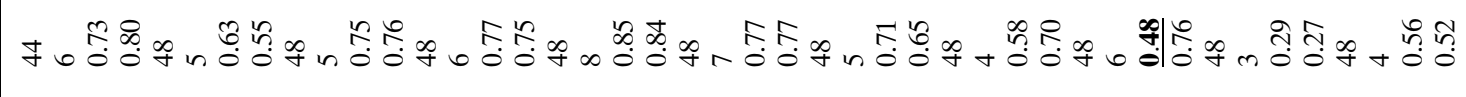 \\
\hline$\frac{5}{>}$ & 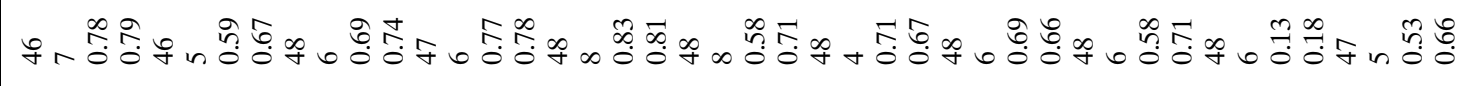 \\
\hline $\begin{array}{c}x \\
3 \\
3\end{array}$ & 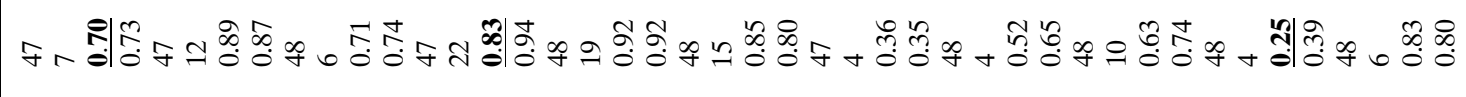 \\
\hline $\begin{array}{l}\infty \\
3 \\
3\end{array}$ & 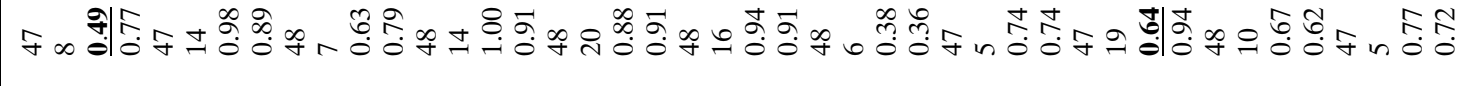 \\
\hline 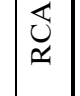 & 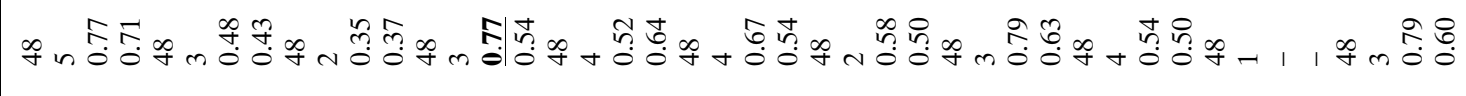 \\
\hline$\ddot{\mathscr{q}}$ & 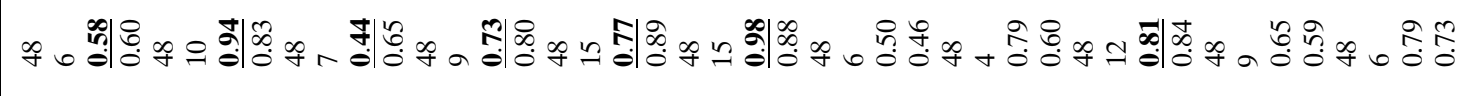 \\
\hline 畄 & 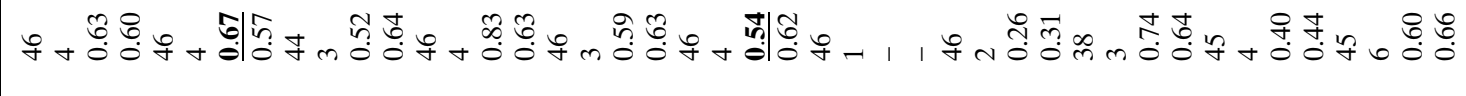 \\
\hline 蚫 & m⿻ \\
\hline 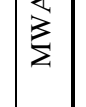 & 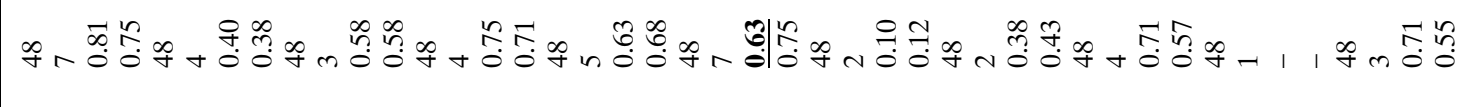 \\
\hline$\sum_{i}^{2}$ & 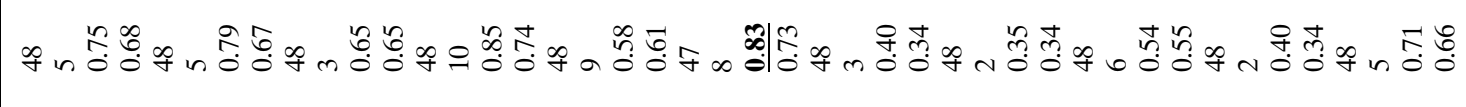 \\
\hline$\sum_{3}^{\frac{\pi}{3}}$ & 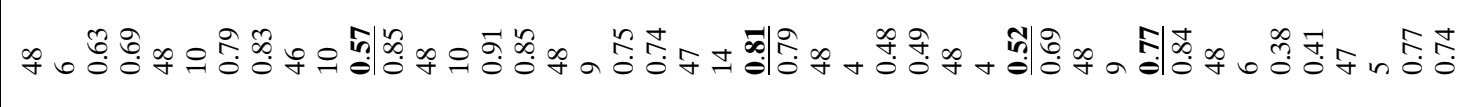 \\
\hline$\sum_{3}^{\infty}$ & 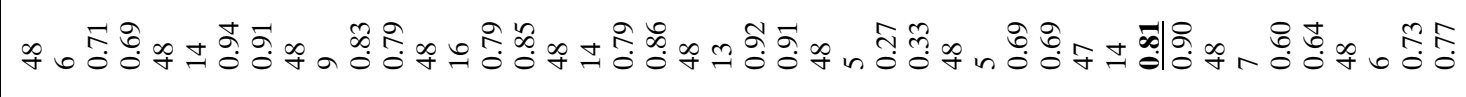 \\
\hline 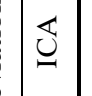 & 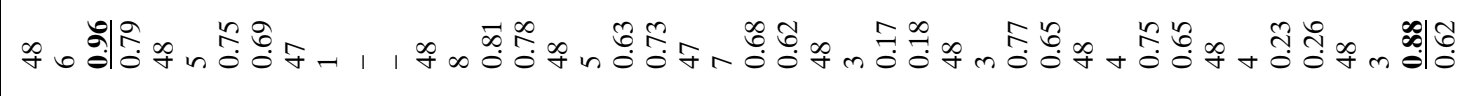 \\
\hline$\sum_{0}^{2}$ & 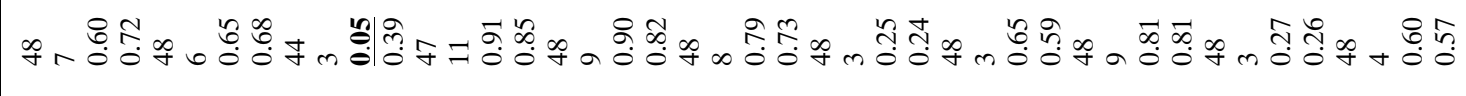 \\
\hline $\mathscr{\mathscr { O }}$ & 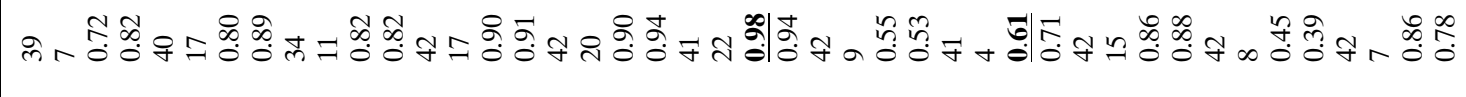 \\
\hline $\begin{array}{l}\sum_{x} \\
\end{array}$ & 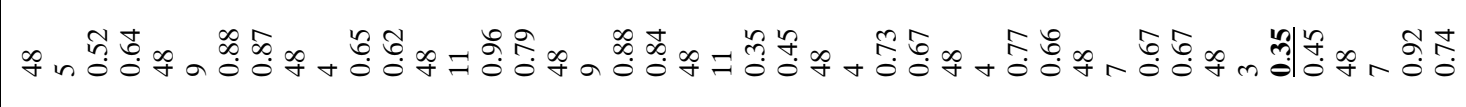 \\
\hline 幽 & 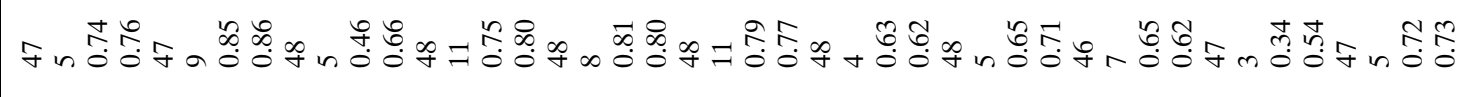 \\
\hline & 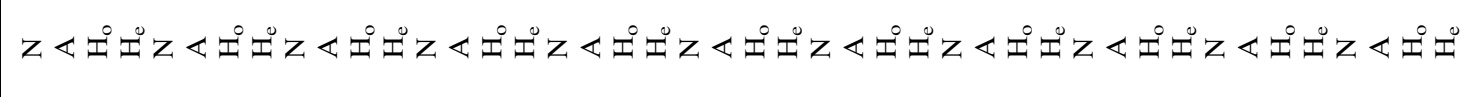 \\
\hline & 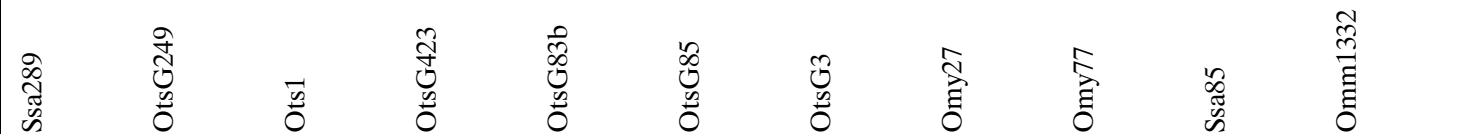 \\
\hline
\end{tabular}




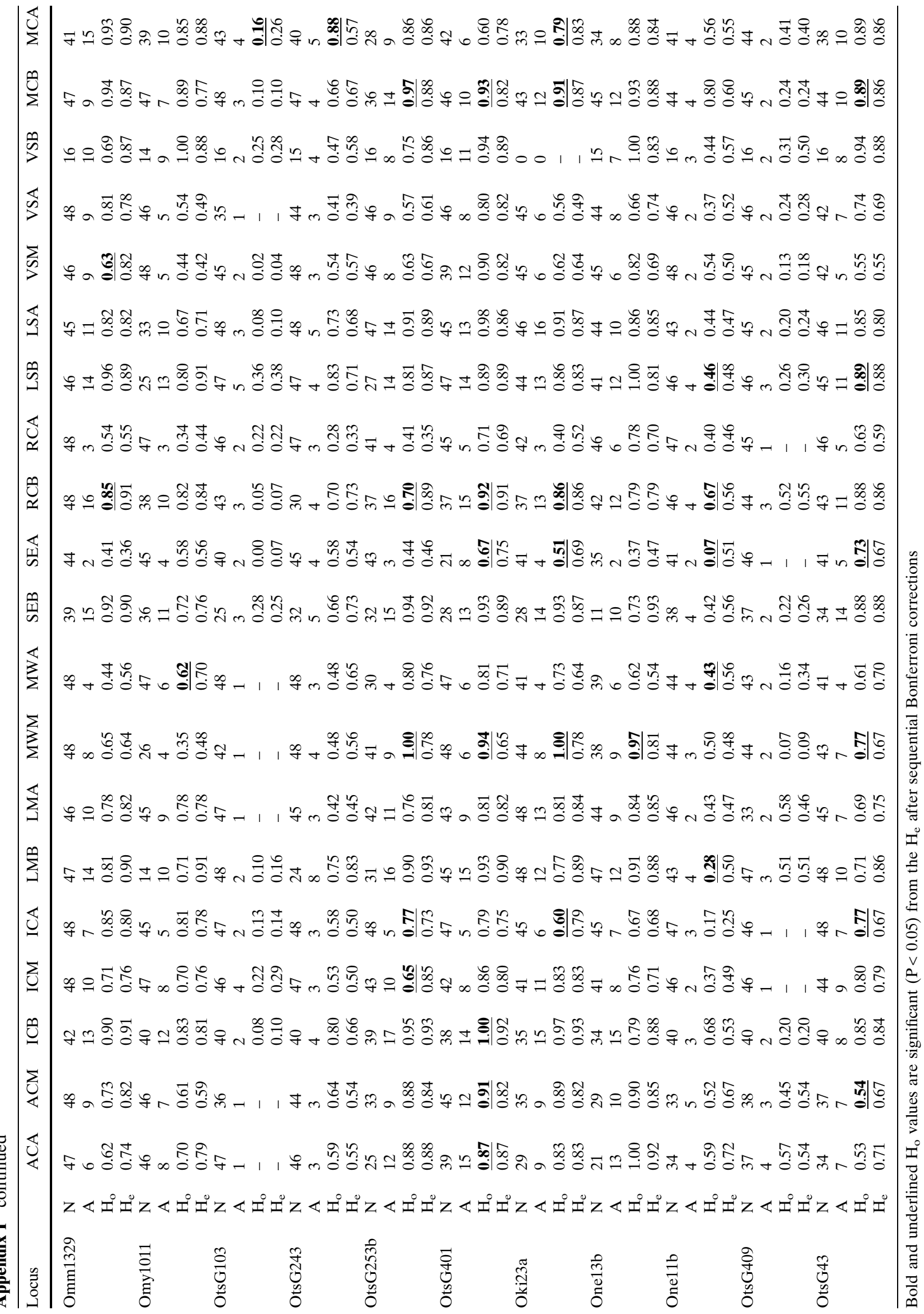




\section{References}

Bagley MJ, Gall GAE (1998) Mitochondrial and nuclear DNA sequence variability of rainbow trout (Oncorhynchus mykiss). Mol Ecol 7:945-961

Banks M, Blouin M, Baldwin B et al. (1999) Isolation and inheritance of novel microsatellites in Chinook salmon (Oncorhynchus tshawytscha). J Hered 90:281-288

Behnke RJ (1972) The systematics of salmonid fishes of recently glaciated lakes. J Fish Res Board Can 29:639-671

Benhke RJ (2002) Comment: first documented case of anadromy in a population of introduced rainbow trout in Patagonia, Argentina. Trans Am Fish Soc 131:582-585

Busby PJ, Wainwright TC, Bryant GJ, Lierheimer LJ, Waples RS, Waknitz FW, Lagomarsino IV (1996) Status review of West Coast steelhead from Washington, Idaho, Oregon, and California. National Marine Fisheries Service, Northwest Fisheries Science Center, Technical Memorandum 27, Seattle

Carlsson J, Nilsson J (2001) Effects of geomorphological structures on genetic differentiation among brown trout populations in a northern boreal river drainage. Trans Am Fish Soc 130:36-45

Castric V, Bonney F, Bernatchez L (2001) Landscape structure and hierarchical genetic diversity in the Brook Charr, Salvelinus fontinalis. Evolution 55:1016-1028

Castric V, Bernatchez L, Belkhir K, Bonhomme F (2002) Heterozygote deficiencies in small lacustrine populations of brook charr Salvelinus fontinalis Mitchill (Pisces, Salmonidae): a test of alternative hypotheses. Heredity 89:27-35

Cavalli-Sforza L, Edwards A (1967) Phylogenetic analysis: models and estimation procedures. Evolution 32:550-570

CDFG (2002) Draft Russian River Restoration Plan (ed. Coey R). California Department of Fish and Game, Yountville, California

Condrey MJ, Bentzen P (1998) Characterization of coastal cutthroat trout (Oncorhynchus clarki) microsatellites and their conservation in other salmonids. Mol Ecol 7:783-792

Cornuet JM, Piry S, Luikart G, Estoup A, Solignac M (1999) New methods employing multilocus genotypes to select or exclude populations as origins of individuals. Genetics 153:1989-2000

Crispo E, Bentson P, Reznick DR, Kinnison MT, Hendry AP (2006) The relative influence of natural selection and geography on gene flow in guppies. Mol Ecol 15:49-62

Currens KP, Schreck CB, Li HW (1990) Allozyme and morphological divergence of rainbow trout (Oncorhynchus mykiss) above and below waterfalls in the Deschutes River, Oregon. Copeia 1990: 730-746

Deiner KL (2004) The effect of landscape features on the genetic structure and diversity of steelhead and rainbow trout (Oncorhynchus mykiss) in the Russian River watershed. MS Thesis, Sonoma State University, California, USA

Excoffier L, Smouse PE, Quattro JM (1992) Analysis of molecular variance inferred from metric distances among DNA haplotypes: application to human mitochondrial DNA restriction data. Genetics 131:479-494

Federal Register (1997) Vol. 62, No. 159, 43937-43954

Felsenstein J (1995) PHYLIP (Phylogeny Inference Package). University of Washington, Box 357360, Seattle, WA 98105, USA

Fleming IA, Jonsson B, Gross MR, Lamberg A (1996) An experimental study of the reproductive behavior and success of farmed and wild Atlantic salmon. J Appl Ecol 33:893-905
Garza JC, Gilbert-Horvath L, Anderson J, Williams T, Spence B, Fish H (2004) Population structure and history of steelhead trout in California. In: Irvine J (ed) Workshop on application of stock identification in defining marine distribution and migration of salmon. North Pacific Anadromous Fish Commission, Honolulu, Hawaii, USA, Nov.1-2, 2003, 5, pp 129-131

Girman DJ, Vilà C, Geffen E, Creel S, Mills MGL, McNutt JW, Ginsberg J, Kat P, Mamiya KH, Wayne RK (2001) Patterns of population subdivision, gene flow and genetic variability in the African wild dog (Lycaon pictus). Mol Ecol 10:17031723.

Goodnight KF, Queller DC (2001) Relatedness v5.0.8. Goodnight Software, Huston

Goudet J (2001) FSTAT, a program to estimate and test gene diversities and fixation indices (version 2.9.3). Available from http://www.unil.ch/izea/softwares/fstat.html

Healey MC (1991) Life history of Chinook salmon (Oncorhynchus tshawytscha). In: Groot C, Margolis L (eds) Pacific salmon life histories. UBC Press, Vancouver, pp 311-394

Heard WR (1991) Life history of pink salmon (Oncorhynchus gorbuscha). In: Groot C, Margolis L (eds) Pacific salmon life histories. UBC Press, Vancouver, pp 119-230

Hedrick PW, Gilpin ME (1997) Genetic effective size of a metapopulation. In: Hanski IA, Gilpin ME (eds) Metapopulation biology: ecology, genetics, and evolution. Academic Press, California, pp 165-181

Hilderbrand RH, Kershner JL (2000) Conserving inland cutthroat trout in small streams: how much stream is enough? N Am J Fish Manage 20:513-520

Hill WG (1981) Estimation of effective population size from data on linkage disequilibrium. Gene Res 38:229-239

King TL, Kalinowski ST, Schill WB, Spidle AP, Lubinski BA (2001) Population structure of Atlantic salmon (Salmo Salar L.): a range-wide perspective from microsatellite DNA variation. Mol Ecol 10:807-821

LeClair LL, Phelps SR, Tynan TJ (1999) Little gene flow from a hatchery strain of chum salmon to local wild populations. $\mathrm{N}$ Am J Fish Manage 19:530-535

Lewis PO, Zaykin D (2001) Genetic data analysis: computer program for the analysis of allelic data, v1.1 (d16c). Program distributed by authors over the internet from http:// www.lewis.eeb.uconn.edu/lewishome/software.html

Manel S, Schwartz MK, Luikart G, Taberlet P (2003) Landscape genetics: combining landscape ecology and population genetics. Trends Ecol Evol 18:189-197

McConnell SK, Hamilton L, Morris D et al (1995) Isolation of salmonid microsatellite loci and their application to population genetics of Canadian east coast stocks of Atlantic salmon. Aquaculture 137:19-30

Moran P, Pendas AM, Garcia-Vazquez E, Izquierdo JT, Rutherford DT (1994) Electrophoresis assessment of the contribution of transplanted Scottish Atlantic salmon (Salmo salar) to the Esva River (Northern Spain). Can J Fish Aquat Sci 51:248-252

Morris DB, Richard KR, Wright JM (1996) Microsatellites from rainbow trout (Oncorhynchus mykiss) and their use for genetic studies of salmonids. Can J Fish Aquat Sci 53:120 126

Moyle PB (2002) Inland fishes of California. University of California Press, London

Nei M, Maruyama T, Charkraborty R (1975) The bottleneck effect and genetic variability in populations. Evolution 29:1-10 
Neraas LP, Spruell P (2001) Fragmentation of riverine systems: the genetic effects of dams on bull trout (Salvelinus confluentus) in the Clark Fork River system. Mol Ecol 10:11531164

Nielsen JL, Fountain MC, Wright JM (1997) Biogeographic analysis of Pacific trout (Oncorhynchus mykiss) in California and Mexico based on mitochondrial DNA and nuclear microsatellites. In: Kocher TD, Stepien CA (eds) Molecular systematics of fishes. Academic Press, London, pp 53-73

Northcote TG (1969) Patterns and mechanisms in lake-ward migratory behavior of juvenile trout. In: Northcote TG (ed) Symposium on salmon and trout streams. Institute of Fisheries, The University of British Columbia, Vancouver, pp 183-203

Olsen JB, Miller SJ, Spearman WJ, Wenburg JK (2003) Patterns of intra- and inter-population genetic diversity in Alaskan coho salmon: implications for conservation. Conserv Genet 4:557-569

O'Reilly PT, Hamilton LC, McConnell SK, Wright JM (1996) Rapid detection of genetic variation in Atlantic salmon (Salmo salar) by PCR multiplexing of dinucleotide and tetranucleotide microsatellites. Can J Fish Aquat Sci 53:22922298

Page RDM (1996) TREEVIEW: an application to display phylogenetic trees on personal computers. Comp Appl Biosci 12:357-358

Palti Y, Fincham MR, Rexroad CE (2002) Characterization of 38 polymorphic microsatellite markers for rainbow trout $(\mathrm{On}$ corhynchus mykiss). Mol Ecol Notes 2:449-452

Poissant J, Knight TW, Ferguson MM (2005) Nonequilibrium conditions following landscape rearrangement: the relative contribution of past and current hydrological landscapes on the genetic structure of a stream-dwelling fish. Mol Ecol 14:1321-1331

Pudovkin AI, Zaykin DV, Hedgecock D (1996) On the potential for estimating the effective number of breeders from heterozygote-excess in progeny. Genetics 144:383-387

Quinn TP (1993) A review of homing and straying of wild and hatchery-produced salmon. Fish Res 18:29-44

Rannala B, Mountain JL (1997) Detecting immigration by using multilocus genotypes. Proc Natl Acad Sci USA 94:91979221

Raymond M, Rousset F (1995) An exact test for population differentiation. Evolution 49:1280-1283

Raymond M, Rousset F (1997) GENEPOP version 3.4, August 1997. University of Montpellier II, Montpellier

Reisner M (1993) Cadillac Desert: The American west and its disappearing water. Revised and updated edition. Penguin Books, New York

Rice WR (1989) Analyzing tables of statistical tests. Evolution 43:223-225

Schneider S, Kueffer J, Roessli D, Excoffier L (2000) Arlequin: a software for population genetic data analysis. Version 2.0. Genetic and Biometry Laboratory, University of Geneva, Switzerland
Scribner KT, Gust JR, Fields RL (1996) Isolation and characterization of novel microsatellite loci: cross-species amplification and population genetic applications. Can J Fish Aquat Sci 53:685-693

Sherwin WB, Moritz C (2000) Managing and monitoring genetic erosion. In: Young AG, Clarke GM (eds) Genetics, demography and viability of fragmented populations. Cambridge University Press, New York, pp 9-34

Small MP, Beacham TD, Withler RE, Nelson RJ (1998) Discriminating coho salmon (Oncorhynchus kisutch) populations within the Fraser River, British Columbia using microsatellite DNA markers. Mol Ecol 7:141-155

Smith CT, Koop BF, Nelson RJ (1998) Isolation and characterization of coho salmon (Oncorhynchus kisutch) microsatellites and their use in other salmonids. Mol Ecol 7:1614-1616

Spidle AP, Schill WB, Lubinski BA, King TL (2001) Fine-scale population structure in Atlantic salmon from Maine's Penobscot River drainage. Conserv Genet 2:11-24

Srikwian S, Woodruff DS (2000) Genetic erosion in isolated small-mammal populations following rainforest fragmentation. In: Young AG, Clarke GM (eds) Genetics, demography and viability of fragmented populations. Cambridge University Press, New York, pp 149-172

Steiner Environmental Consulting (1996) A history of the salmonid decline in the Russian River. Potter Valley, CA pp 1-86

Taberlet P, Bouvet J (1991) A single plucked feather as a source of DNA for bird genetic studies. Auk 108:959-960

Takezaki N, Nei M (1996) Genetic distances and reconstruction of phylogenetic trees from microsatellite DNA. Genetics 144:389-399

Waples RS (1991) Genetic interactions between hatchery and wild salmonids: lessons from the Pacific Northwest. Can J Fish Aquat Sci 48:124-133

Weir BS, Cockerham CC (1984) Estimating F-statistics for the analysis of population structure. Evolution 138:1358-1370

Weir BS, Cockerham CC (1996) Genetic data analysis II: methods for descrete population genetic data. Sinauer Assoc., Inc., Sunderland, MA, USA

Wenburg JK, Bentzen, P (2001) Genetic and behavioral evidence for restricted gene flow among coastal cutthroat trout populations. Trans Am Fish Soc 130:1049-1069

Williams RN, Leary RF, Currens KP (1997) Localized genetic effect of a long-term hatchery stocking program on resident rainbow trout in the Metolius River. N Am J Fish Manage 17:1079-1093

Williamson KS, Cordes JF, May BP (2002) Characterization of microsatellite loci in Chinook salmon (Oncorhynchus tshawytscha) and cross-species amplification in other salmonids. Mol Ecol Notes 2:17-19

Wishard LN, Seeb JE, Utter FM, Stefan D (1984) A genetic investigation of suspected redband trout populations. Copeia 1984:120-132 